\title{
The Anti-Promyelocytic Leukemia Mode of Action of Two Endophytic Secondary Metabolites Unveiled by a Proteomic Approach
}

Authors

Affiliations
Margareth B. C. Gallo ${ }^{1,2,3}$, Miranda J. S. Falso ${ }^{4}$, Fernanda Balem ${ }^{5}$, Diego Menezes ${ }^{3,6}$, Núbia Rocha ${ }^{6}$, Raghavan Balachandran ${ }^{1}$, Timothy S. Sturgeon ${ }^{7}$, Mônica T. Pupo ${ }^{2}$, Billy W. Day ${ }^{1}$

The affiliations are listed at the end of the article
Key words

- Papulaspora immersa

- Trichosphaeriaceae

- Nigrospora sphaerica

- aphidicolin

- epoxyergostane-type steroid
- Chaetomiaceae

\section{Abstract \\ $\nabla$}

As a result of a program to find antitumor compounds of endophytes from medicinal Asteraceae, the steroid (22E,24R)-8,14-epoxyergosta-4,22-diene-3,6-dione (a) and the diterpene aphidicolin (b) were isolated from the filamentous fungi $\mathrm{Pa}$ pulaspora immersa and Nigrospora sphaerica, respectively, and exhibited strong cytotoxicity against HL-60 cells. A proteomic approach was used in an attempt to identify the drugs' molecular targets and their respective antiproliferative mode of action. Results suggested that the (a) growth inhibition effect occurs by G2/M cell cycle arrest via reduction of tubulin alpha and beta isomers and 14-3-3 protein gamma expression, followed by a decrease of apoptotic and inflammatory proteins, culminating in mitochondrial oxi-

\section{Introduction}

$\nabla$

received Dec. 20, 2013

revised January 27, 2014

accepted February 22, 2014

Bibliography

Dol http://dx.doi.org/

10.1055/s-0034-1368301

Published online April 7, 2014

Planta Med 2014; 80: 473-481

(C) Georg Thieme Verlag KG

Stuttgart · New York ·

ISSN 0032-0943

Correspondence

Prof. Dr. Margareth Borges

Coutinho Gallo

Mass Spectrometry Core Facility

Centro de Pesquisas Gonçalo

Moniz (CPqGM) - FIOCRUZ

Rua Waldemar Falcão, 121,

Candeal

Salvador, BA, 40296-710

Brazil

Phone: + 552133485113

Fax: + 552133485050

margarethgallo@far.fiocruz.br
An estimated 48610 new cases of leukemia and 23720 deaths due to it were expected to occur in the US in 2013 [1]. Leukemia is a broad term covering a variety of diseases. Acute promyelocytic leukemia (APL) is a subtype of acute myelogenous leukemia, a cancer of the blood and bone marrow. The prognosis of APL has been considerably enhanced by the use of all trans retinoic acid (ATRA) and arsenic trioxide (ATO). The use of these drugs is, however, narrowed by resistance to ATRA and the side effects of ATO [2], motivating the exploration for compounds bearing new mechanisms of action.

In our search to find endophytes in medicinal Asteraceae as potential new anticancer secondary metabolite producers, we have isolated several endophytic fungi from Yacon tissues. Among them, Papulaspora immersa H.H. Hoston (Chaetomiaceae) and Nigrospora sphaerica (Sacc.) E.W. Mason (Trichosphaeriaceae) yielded the natural dative damage that triggered autophagy-associated cell death. Moreover, the decrease observed in the expression levels of several types of histones indicated that (a) might be disarming oncogenic pathways via direct modulation of the epigenetic machinery. Effects on cell cycle progression and induction of apoptosis caused by (b) were confirmed. In addition, protein expression profiles also revealed that aphidicolin is able to influence microtubule dynamics, modulate proteasome activator complex expression, and control the inflammatory cascade through overexpression of thymosin beta 4, RhoGDI2, and 14-33 proteins. Transmission electron micrographs of (b)-treated cells unveiled dose-dependent morphological characteristics of autophagy- or oncosis-like cell death.

products $\quad(22 E, 24 R)-8,14$-epoxyergosta-4,22-diene-3,6-dione (a) and aphidicolin (b), respectively ( Fig. 1). These agents exhibit cytotoxic activities against some human tumor cells, including HL-60 promyelocytic leukemia cells ( IC $_{50}$ values of $1.65 \mu \mathrm{M}$ and $0.27 \mu \mathrm{M}$, correspondingly) [3,4]. Aphidicolin is an antibiotic and cytotoxic diterpene first isolated from cultures of the fungus Cephalosporium aphidicola Petch (Hypocreaceae). This agent prevents DNA synthesis by inhibition of DNA polymerase $\alpha$ and $\delta$ [5], binding reversibly to the enzymes and not to DNA, and is selectively toxic in the S-phase of the cell cycle [6]. Schimke and coworkers demonstrated that the mode of action of (b) on HeLaS3 cells depends on the concentration and duration of exposure, ranging from complete apoptosis in the early S-phase to inhibition of progression through the S-phase to different degrees, with cells eventually undergoing mitosis with the extensive generation of microcells. They also observed that some cells "escaped" the early S-phase apoptotic position, 


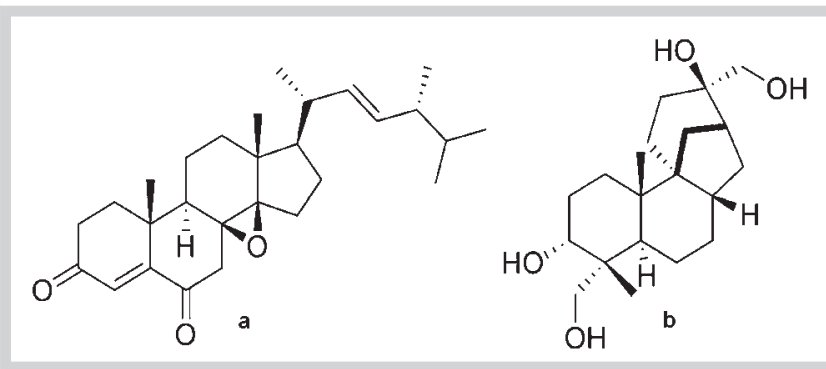

Fig. 1 Structures of (22E,24R)-8,14-epoxyergosta-4,22-diene-3,6-dione (a) and aphidicolin (b).

transitioned to aberrant mitosis, and underwent apoptosis as a consequence of aberrant mitotic events [7]. The study of HL-60 cells shows that (b) increases the phosphorylation of histone $\mathrm{H} 2 \mathrm{AX}$ in the early S-phase, inducing DNA damage [8]. Activation of deoxycytidine kinase ( $\mathrm{dCK}$ ) was also detected [9], perhaps explaining the synergistic effect that (b) exhibits in the combined treatment of HL-60 cells with ATRA [10].

Epoxyergostane-type steroids have exhibited cytotoxicity against a variety of tumor cell lines. For example, $2 \mu \mathrm{M}$ stoloniferones from the soft coral Clavularia (Clavularidae) cause $69 \%$ of the growth inhibition of P-388 leukemia cells [11]; withaferin A, present in some genera of Solanaceae, displays IC $_{50}$ values in the range of 0.5 to $2.2 \mu \mathrm{M}$ against several cancer cell lines [12].

Steroid-based regimens are frequently used to treat APL patients affected with retinoic acid syndrome, a serious complication derived from the treatment with ATRA. Dexamethasone (DEX), one of the most used synthetic glucocorticoids (GC) to treat that problem, also displays an antiproliferative effect itself [13], and bears structural resemblance with human GCs. In general, the effect of GCs on lymphoid cells includes G1-phase cell cycle arrest and apoptosis [14]. GCs mediate many of their anti-inflammatory and cytotoxic effects through the inhibition of NF- $k$ B [15]. Laane et al. showed that DEX-induced cell death involves autophagy triggered by dephosphorylation of Akt preceding the manifestation of a massive mitochondria-dependent apoptosis [16]. Samadi et al. described the antiproliferative action of withaferin A through $\mathrm{G}_{2} / \mathrm{M}$ cell cycle arrest and apoptosis, also a result of Akt deactivation [12].

The present investigation was undertaken in an attempt to elucidate the actual mechanism behind the induction of HL-60 cell growth inhibition and cytotoxicity by compounds (a) and (b) using a proteomic approach.

\section{Results}

$\nabla$

Taking into account what is known regarding the cytotoxicity of fungal secondary metabolites [3,4], the HL-60 promyelocytic leukemia cell line was chosen. The cells were treated with (a) and (b), and the proteomes of drug-treated and control cells were determined to find the proteins with altered levels. It was hoped that an analysis would aid in finding the drugs' antiproliferative modes of action.

After $48 \mathrm{~h}$ of treatment, cells were harvested, counted, and the cell growth inhibitory activity was determined ( $\bullet$ Table 1 ), corroborating the earlier observed cytotoxic outcomes. Subsequently, cellular proteins were extracted using two different but
Table 1 Growth inhibition of HL-60 cells caused by (22E,24R)-8,14-epoxyergosta-4,22-diene-3,6-dione (a) and aphidicolin (b).

\begin{tabular}{|lc} 
Sample concentration $(\boldsymbol{\mu M})$ & Growth inhibition (\%) \\
\hline (a) $(1.65)$ & 57.1 \\
\hline (a) $(4.95)$ & 85.7 \\
\hline (b) $(0.40)$ & 100.0 \\
\hline (b) $(2.66)$ & 142.8 \\
\hline
\end{tabular}

Negative control: $0.1 \%$ DMSO treated cells. Positive control: Doxorubicin IC $500.40 \mathrm{nM}$

consecutive lysis buffers, a modified RIPA (radio immunoprecipitation assay) buffer, and a urea-based buffer. Aliquots of the extracts containing $100 \mu \mathrm{g}$ of protein were denatured, reduced, alkylated, digested, and labeled with isobaric tags for relative and absolute quantitation (iTRAQ) 8-plex reagents. Samples were submitted to strong cation exchange (SCX) chromatography using a salt gradient elution, and fractions were subsequently fractionated by nanoHPLC.

MALDI/TOF-MS/MS analysis of the LC-fractionated iTRAQ-labeled peptides from the RIPA- and urea-based buffers' lysates of (b)-treated cells ( Tables 2 and 3, respectively) revealed that cells treated with $0.4 \mu \mathrm{M}$ (b) exhibited significant elevated levels of several proteins like POTEF, transgelin-2, tubulin $\alpha$, stathmin (STAT), and RhoGDI2, among others. Lowered levels of histones H2A type 1 and H1.4, and the proteasome activator complex subunit 1 were also observed. Cells treated with $2.66 \mu \mathrm{M}$ (b) showed a similar protein profile except that tubulin $\alpha$, cofilin-1, and 143-3 proteins were present at control levels.

MS/MS analyses of fractions derived from cells treated with $1.65 \mu \mathrm{M}(\mathbf{a})$ displayed significant lowered levels of all the proteins detected in the RIPA lysates ( Table 2 ), as well some members of the 14-3-3 protein family and hnRNP A2/B1 from urea lysates ( Table 3). Notably, the majority of proteins detected from cells treated with a higher concentration $(4.95 \mu \mathrm{M})$ of $(\mathbf{a})$ exhibited protein levels equivalent to the untreated cells, except for the levels of RhoGDI2, SET, TB4, MIF, and some $14-3-3$ protein isomers that were lowered.

Cell cycle progression and cell death were examined with flow cytometric analyses. HL-60 cells treated with $0.4 \mu \mathrm{M}$ (b) showed significant arrest in the S-phase ( Table 4), and cells underwent apoptosis, which was markedly increased in $2.66 \mu \mathrm{M}$ (b)-treated cells

Cells treated with $1.65 \mu \mathrm{M}$ (a) showed a moderate $\mathrm{G}_{2} / \mathrm{M}$-phase arrest, which increased significantly in cells treated with $4.95 \mu \mathrm{M}(\mathrm{a})$, but no apoptosis was observed ( Table 4).

In order to ascertain how (a)-treated cells died, and to correlate death with the changes in protein levels, scanning (SEM) and transmission electron microscopic (TEM) analyses were performed. Representative SEM micrographs of untreated and (a)treated HL-60 cells are shown in $\odot$ Fig. 2. Untreated cells exhibited a rounded and smooth surface ( $\bullet$ Fig. $2 \mathrm{C}$ ) while cells treated with $1.65 \mu \mathrm{M}$ (a) had a moderate reduction in size accompanied by a lumpy and blebbing membrane ( Fig. 2A). Cells treated with $4.95 \mu \mathrm{M}$ (a) showed a complex surface morphology with a combination of a coarse membrane presenting scale-like ultrastructures, a smooth surface with numerous folds ( Fig. 2B), and some microvilli or accentuated blebs. TEM micrographs of untreated cells ( $\odot$ Fig. $3 \mathrm{C}$ ) showed a few enlarged rough endoplasmic reticula (ER); mitochondria (MT) were either elongated or rounded with simple tubular cristae; vacuolar and granular 
Table 2 Proteins found at levels different from the control ${ }^{a}$ after HL-60 cells were treated with (22E,24R)-8,14-epoxyergosta-4,22-diene-3,6-dione (a) and aphidicolin (b) detected in RIPA lysates ( $\mathrm{x} \leq 0.05$; $99 \%$ confidence).

\begin{tabular}{|c|c|c|c|c|c|c|c|}
\hline $\begin{array}{l}\text { Accession number } \\
\text { UniProtKB/Swiss Prot }\end{array}$ & Protein name & $\begin{array}{l}\text { Number of } \\
\text { peptides } \\
\text { identified }\end{array}$ & $\begin{array}{l}\text { Sequence } \\
\text { coverage } \\
(\%)\end{array}$ & $\begin{array}{l}114: 113 \\
\text { ratio }^{b}\end{array}$ & $\begin{array}{l}115: 113 \\
\text { ratio }^{b}\end{array}$ & $\begin{array}{l}\text { 119: } 118 \\
\text { ratioc }^{c}\end{array}$ & $\begin{array}{l}121: 118 \\
\text { ratioc }^{c}\end{array}$ \\
\hline P0COS8 & Histone $\mathrm{H} 2 \mathrm{~A}$ type 1 & 4 & 76.6 & 0.8040 & 0.8187 & 0.5719 & 1.0108 \\
\hline P10412 & Histone H1.4 & 2 & 77.6 & 0.7442 & 0.6577 & 0.8063 & 1.0329 \\
\hline Q06323 & $\begin{array}{l}\text { Proteasome activator complex } \\
\text { subunit } 1\end{array}$ & 1 & 18.0 & 0.6819 & 1.0164 & - & - \\
\hline B4E3A4 & $\begin{array}{l}\text { cDNA FLJ57283, highly similar to } \\
\text { actin cytoplasmic } 2\end{array}$ & 5 & 26.7 & - & - & 0.6988 & 0.9997 \\
\hline Q5QNW6 & Histone H2B type 2-F & 5 & 61.9 & - & - & 0.7902 & 1.0816 \\
\hline P04406 & GAPDH & 2 & 32.2 & - & - & 0.6746 & 0.9836 \\
\hline Q5VTE0 & $\begin{array}{l}\text { Putative elongation factor } \\
\text { 1-alpha-like } 3\end{array}$ & 2 & 13.9 & - & - & 0.8592 & 0.9751 \\
\hline P07437 & Tubulin beta chain & 1 & 17.1 & - & - & 0.8576 & 1.0707 \\
\hline P05164 & Isoform $\mathrm{H} 7$ of myeloperoxidase & 1 & 16.7 & - & - & 0.7906 & 1.0497 \\
\hline P62805 & Histone H4 & 1 & 52.4 & - & - & 0.8594 & 1.0406 \\
\hline P14174 & $\begin{array}{l}\text { Macrophage migration } \\
\text { inhibitory factor (MIF) }\end{array}$ & 1 & 13.0 & - & - & 0.6116 & 0.8524 \\
\hline P16403 & Histone H1.2 & 1 & 75.6 & - & - & 0.6739 & 0.9720 \\
\hline P49736 & $\begin{array}{l}\text { DNA replication licensing } \\
\text { factor MCM2 }\end{array}$ & 1 & 10.2 & - & - & 0.8383 & 0.9823 \\
\hline Q5E9F8 & Histone H3.3 & 1 & 37.2 & - & - & 0.7646 & 0.9818 \\
\hline P39687 & $\begin{array}{l}\text { Acidic leucine-rich nuclear } \\
\text { phosphoprotein } 32 \text { family } \\
\text { member A (ANP32A) }\end{array}$ & 1 & 16.7 & - & - & 0.8365 & 1.1528 \\
\hline
\end{tabular}

${ }^{a}$ Downregulated cell ratio: $\leq 0.9$, upregulated cell ratio: $>2.0 ;{ }^{b}$ (b)-treated cells: 114 -labeled: $0.15 \mu \mathrm{g} / \mathrm{mL}(0.4 \mu \mathrm{M}), 115$-labeled: $0.9 \mu \mathrm{g} / \mathrm{mL}(2.66 \mu \mathrm{M}), 113$-labeled: control; c (a)-treated cells: 119 -labeled: $0.7 \mu \mathrm{g} / \mathrm{mL}(1.65 \mu \mathrm{M}), 121$-labeled: $2.1 \mu \mathrm{g} / \mathrm{mL}(4.95 \mu \mathrm{M}), 118$-labeled: control

Table 3 Proteins found at levels different from the control a after HL-60 cells were treated with (22E,24R)-8,14-epoxyergosta-4,22-diene-3,6-dione (a) and aphidicolin (b) detected in urea lysates ( $\mathrm{p} \leq 0.05 ; 99 \%$ confidence).

\begin{tabular}{|c|c|c|c|c|c|c|c|}
\hline $\begin{array}{l}\text { UniProtKB/Swiss Prot } \\
\text { accession number }\end{array}$ & Protein name & $\begin{array}{l}\text { Number of } \\
\text { peptides } \\
\text { identified }\end{array}$ & $\begin{array}{l}\text { Sequence } \\
\text { coverage } \\
(\%)\end{array}$ & $\begin{array}{l}116: 121 \\
\text { ratio }^{b}\end{array}$ & $\begin{array}{l}117: 121 \\
\text { ratio }^{b}\end{array}$ & $\begin{array}{l}\text { 118: } 121 \\
\text { ratioc }^{c}\end{array}$ & $\begin{array}{l}\text { 119: } 121 \\
\text { ratioc }^{c}\end{array}$ \\
\hline Q71U36 & Tubulin alpha-1A chain & 3 & 23.5 & 0.9511 & 0.6550 & 1.3065 & 3.1746 \\
\hline P23528 & Cofilin-1 & 3 & 41.0 & 1.2929 & 0.8571 & 1.4266 & 2.7444 \\
\hline A543E0 & $\begin{array}{l}\text { POTE ankyrin domain family } \\
\text { member } F \text { (POTEF) }\end{array}$ & 3 & 9.0 & 1.3534 & 0.9009 & 2.2351 & 5.5696 \\
\hline P61981 & 14-3-3 protein gamma & 2 & 27.1 & 0.8486 & 0.8810 & 0.9284 & 1.9005 \\
\hline P62328 & Thymosin beta- 4 & 2 & 57.1 & 0.8035 & 1.5497 & 2.0208 & 2.6360 \\
\hline P63104 & 14-3-3 protein zeta/delta & 2 & 26.9 & 1.0069 & 1.0984 & 1.2762 & 2.3182 \\
\hline P16949 & Stathmin & 1 & 32.2 & 1.1478 & 1.2310 & 2.8582 & 2.9654 \\
\hline P22626 & $\begin{array}{l}\text { Heterogeneous nuclear ribonu- } \\
\text { cleoproteins A2/B1 (hnRNPA2/ } \\
\text { B1) }\end{array}$ & 1 & 19.2 & 1.6932 & 0.792 & 3.1816 & 3.3888 \\
\hline P37802 & Transgelin-2 & 1 & 24.6 & 1.1994 & 1.3122 & 2.2345 & 2.9802 \\
\hline P31946 & 14-3-3 Protein beta/alpha & 2 & 23.8 & 0.5587 & 0.5989 & 0.6119 & 1.6229 \\
\hline Q53S41 & $\begin{array}{l}\text { Putative uncharacterized } \\
\text { protein YWHAQ (14-3-3 } \\
\text { protein theta) }\end{array}$ & 2 & 22.8 & 0.3941 & 0.9020 & 1.3707 & 2.6182 \\
\hline Q01105 & Protein SET isoform 1 & 1 & 17.6 & 0.6438 & 1.7615 & 1.0035 & 3.0154 \\
\hline P52566 & $\begin{array}{l}\text { Rho GDP-dissociation inhibitor } 2 \\
\text { (RhoGDI2) }\end{array}$ & 1 & 15.1 & 0.7822 & 1.0647 & 2.2386 & 3.5025 \\
\hline
\end{tabular}

${ }^{a}$ Downregulated cell ratio: $\leq 0.9$, upregulated cell ratio: > 2.0; ${ }^{\text {b }}$ a-treated cells: 117 -labeled: $0.7 \mu \mathrm{g} / \mathrm{mL}(1.65 \mu \mathrm{M}), 116$-labeled: $2.1 \mu \mathrm{g} / \mathrm{mL}(4.95 \mu \mathrm{M}), 121$-labeled: control; ' b-treated cells: 119 -labeled: $0.15 \mu \mathrm{g} / \mathrm{mL}(0.4 \mu \mathrm{M}), 118$-labeled: $0.9 \mu \mathrm{g} / \mathrm{mL}(2.66 \mu \mathrm{M}), 121$-labeled: control

structures were poorly developed; nuclei appeared with an irregular shape. Cells treated with $1.65 \mu \mathrm{M}$ (a) displayed marked swelling of MT with vacuolization, disintegrated cristae, decreased matrix density, and, eventually, rupture of the mem- brane ( $\odot$ Fig. $3 \mathrm{~A}$ ); increases in peroxisome and dilated ER numbers were observed. Also, ER invagination and engulfing of cytoplasmic organelles occurred, initiating the formation of autophagic vacuoles (AV) as suggested by Dunn jr. [17]. Cells treated with 


\begin{tabular}{|llll|} 
Sample (concentration $\boldsymbol{\mu M})$ & Cell cycle distribution (\%) & & \\
& $\mathbf{G}_{0} / \mathbf{G}_{1}$ & $\mathbf{S}$ & $\mathbf{G}_{\mathbf{2}} / \mathbf{M}$ \\
\hline Negative control & $68.6 \pm 5.7$ & $24.5 \pm 0.1$ & $3.7 \pm 0.3$ \\
\hline (a) $(1.65)$ & $63.2 \pm 7.9$ & $27.9 \pm 2.7$ & $5.0 \pm 3.1$ \\
\hline (a) $(4.95)$ & $69.8 \pm 14.1$ & $22.8 \pm 2.4$ & $6.9 \pm 2.7^{*}$ \\
\hline (b) $(0.40)$ & $61.1 \pm 1.8^{*}$ & $28.0 \pm 5.8^{*}$ & $1.3 \pm 1.9$ \\
\hline
\end{tabular}

Table 4 Effect of (22E,24R)-8,14epoxyergosta-4,22-diene-3,6-dione (a) and aphidicolin (b) on HL60 cell cycle distribution measured by flow cytometry.

* Statistical significance between treated and negative control cells $(p<0.05$; Student's t-test). Data are presented as mean \pm SD $(n=2)$
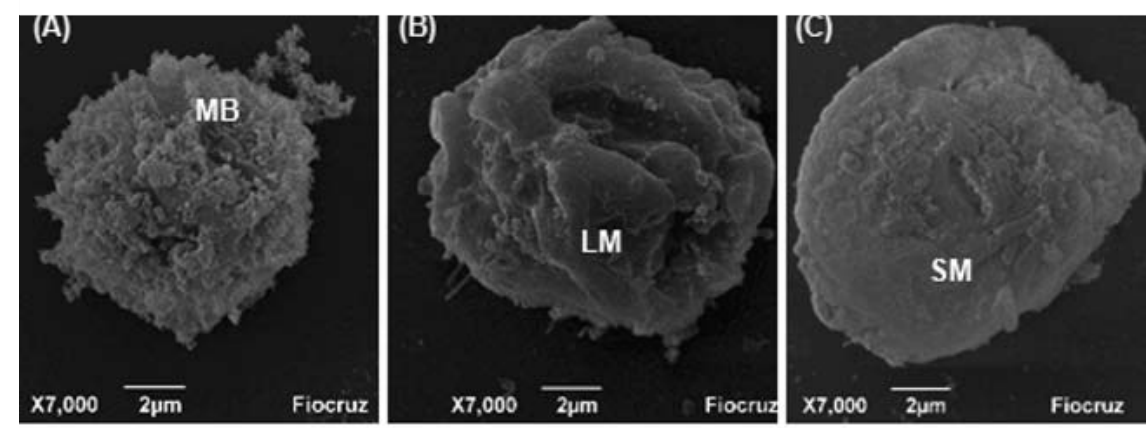

Fig. 2 Scanning electron micrographs of HL-60 cells. A Cells treated with $1.65 \mu \mathrm{M}$ (a); B Cells treated with $4.95 \mu \mathrm{M}(\mathbf{a})$; C Vehicle control; D Cells treated with $0.4 \mu \mathrm{M}(\mathbf{b})$; and $\mathbf{E}$ Cells treated with $2.66 \mu \mathrm{M}$ (b). MB: membrane blebbing; LM: lumpy membrane; SM: smooth membrane; MV: microvilli; AB: apoptotic body; CM: cracked membrane.
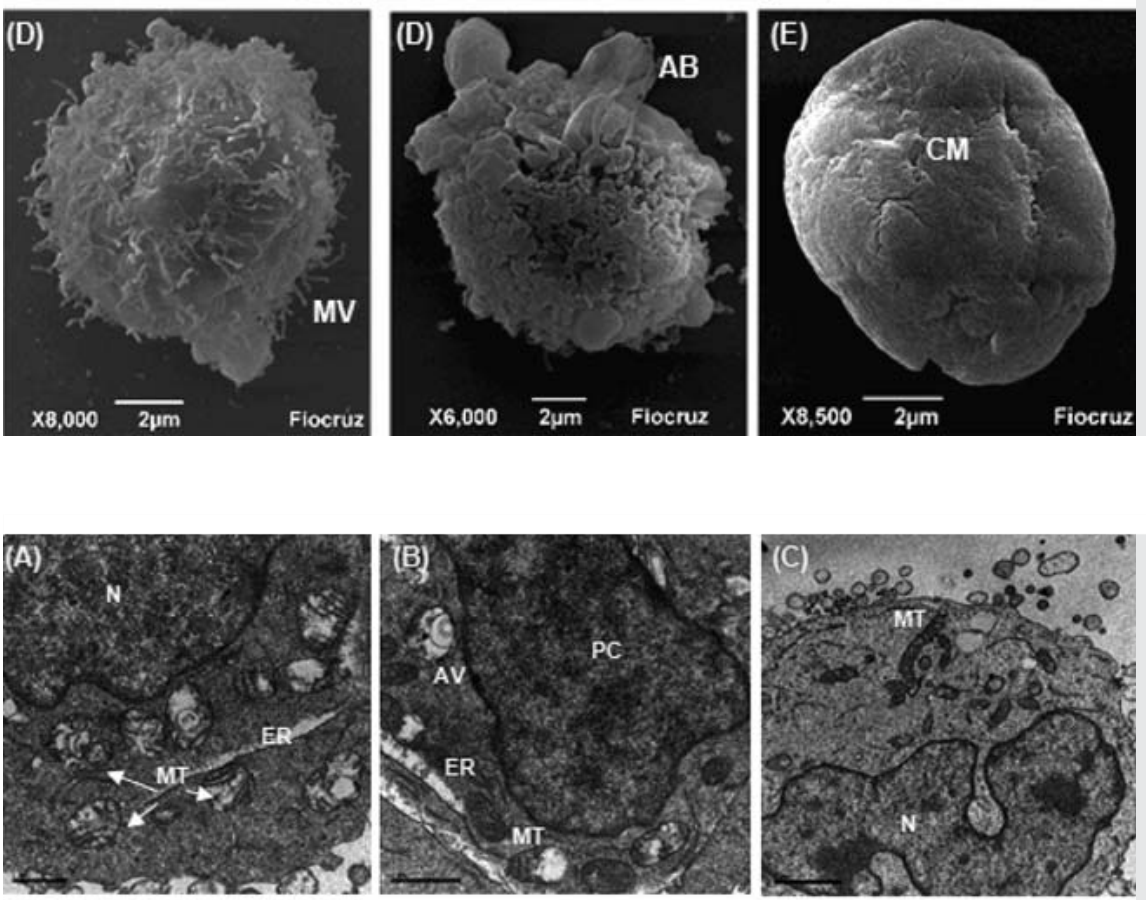

Fig. 3 Transmission electron micrographs of $\mathrm{HL}-$ 60 cells. A Cells treated with $1.65 \mu \mathrm{M}$ (a); B Cells treated with $4.95 \mu \mathrm{M}(\mathbf{a})$; $\mathbf{C}$ Vehicle control; $\mathbf{D}$ Cells treated with $0.4 \mu \mathrm{M}(\mathbf{b})$; and $\mathbf{E}$ Cells treated with $2.66 \mu \mathrm{M}$ (b). Magnifications and bar lengths: $\mathbf{A}$ $20 \mathrm{~K} \times 1 \mu \mathrm{m} ; \mathbf{B} 25 \mathrm{~K} \times 1 \mu \mathrm{m} ; \mathbf{C} 12 \mathrm{~K} \times 2 \mu \mathrm{m} ; \mathbf{D} 60 \mathrm{~K} \times$ $0.5 \mu \mathrm{m} ; \mathbf{E} 16 \mathrm{~K} \times 5 \mu \mathrm{m}$; and E2 50K $\times 0.5 \mu \mathrm{m}$. ER: enlarged endoplasmic reticulum cisternae; MT: mitochondria; N: nucleus; PC: patchy chromatin condensation; AV: autophagic vacuole containing
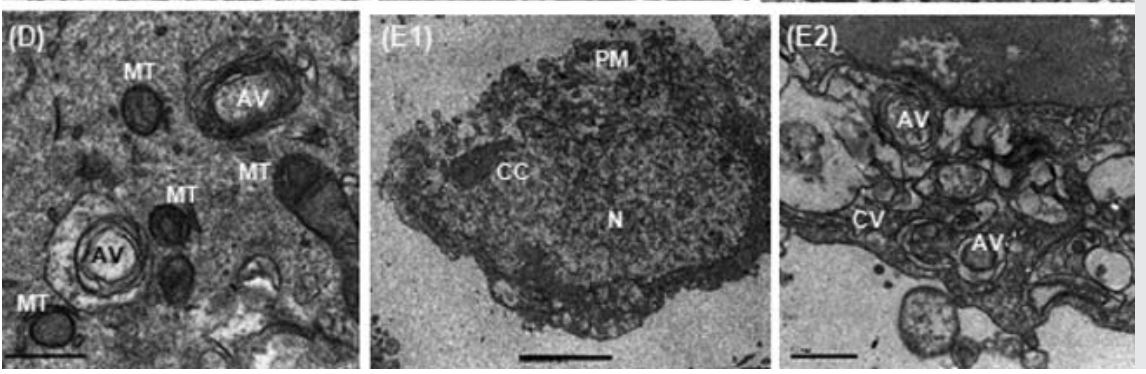
membranous whorls; CC: clumping of chromatin along the nuclear membrane; $\mathrm{CV}$ : cytoplasmic vacuolation; PM: plasma membrane disruption.

$4.95 \mu \mathrm{M}$ (a) exhibited prominent profiles of enlarged ER, an increased number of AVs, and a swelled MT with striking vacuolization and degradation (๑ Fig. 3B).

SEM analysis of cells treated with $0.4 \mu \mathrm{M}$ (b) exhibited surfaces with extensive microvilli or blebbing and formation of apoptotic bodies (AB; $\odot$ Fig. 2D). TEM analysis exhibited clumping of chromatin along the nuclear membrane, formation of $A B$ containing intact organelles, and AV surrounded by curled membranes ( Fig. 3D). At a higher concentration of (b) $(2.66 \mu \mathrm{M})$, SEM showed just a few cells possessing either a cracked ( Fig. $2 \mathrm{E}$ ) or a completely disrupted cytoplasmic membrane, which was confirmed by TEM analysis that displayed cells with a ruptured plasma membrane, an uneven electron-lucent nucleus ( $\odot$ Fig. 3E1), and a plethora of AV ( $\odot$ Fig. 3E2), all indicating a necrosis-like cell 
death was occurring [18]. Alternatively, some cells displayed apoptosis features.

To further validate the level of differentially expressed proteins, Western blotting analyses were carried out ( $\bullet$ Fig. 4). The overexpression of STAT and TB4 by (b)-treated cells was confirmed as well as the hypo-expression of tubulin by (a)-treated cells.

\section{Discussion}

$\nabla$

With respect to the mode of action of (b), an apoptotic profile was confirmed by SEM and TEM micrographs and seems to be orchestrated by the increased levels of POTEF (a protein reported to function as a proapoptotic factor [19]), hnRNP A2/B, and RhoGDI2. Higher levels of RhoGDI2 ultimately sensitize HL-60 cells to caspase-3-mediated apoptosis [20], and elicit an autoimmune response in acute leukemia [21]. RhoGDI2, along with hnRNP A2/ $\mathrm{B} 1$, are among the ten most frequently observed human proteins in proteome analyses of apoptotic cells [22]. The Rho family of GTPases plays an important role in cell morphology, cell cycle, and programmed cell death progression, controlling actin cytoskeleton rearrangement, blebbing, fragmentation, and phagocytosis of apoptotic cells [23]. Moreover, lowered levels of hnRNP A2/ $\mathrm{B} 1, \mathrm{SET}$, and RhoGDI2 indicate chemoresistance in ovarian tumor tissues treated with paclitaxel, a microtubule stabilizer and apoptosis-inducing drug [24]. Microtubules are formed by alpha and beta tubulin heterodimers that have a short half-life, so they are in constant assembly or disassembly, a dynamic instability controlled by STAT, which promotes depolymerization of microtubules and/or prevents polymerization of tubulin heterodimers. Overexpression of STAT in mitotic cells induces a misaligned distribution of chromosomes at the metaphase plate, impairing the formation of a functional mitotic spindle [25]. The aberrant chromosome segregation and cell division observed by Schimke et al. [7] in HeLaS3 cells treated with (b) might be a consequence from defects in assembly and a function of the mitotic spindle caused by STAT overload, which also activates the intrinsic apoptosis pathway [26].

The hypo-expression of histones H2A and H1.4 observed in cells treated with (b) corroborates the results of Kurose et al. [8], suggesting that DNA damage and cell growth arrest caused by (b) involve those proteins that may be downregulated by the increased level of SET, a multitasking protein subunit of the INHAT complex (inhibitor of histone acetyltransferases) [27]. It is known that H1.2 inhibition causes defects in the chromatin structure and changes in the expression of specific genes linked to the cell cycle [28]. The observed decreased level of proteasome activator complex subunit 1, which is involved in DNA damage response and the S-phase of mitotic cell cycle arrest, might also play an additional role in this process. Increased levels of cofilin- 1 and transgelin-2, proteins involved in cytoskeleton organization $[29,30]$, reinforce the hypothesis that the tumor suppressor activity of (b) might occur by actin destabilization.

In relation to the mode of action of compound (a), the observed downregulation of 14-3-3 proteins could influence the G2/M transition of the mitotic cells cycle, thereby directing the cell to die by means other than apoptosis. It is well known that a reduction in 14-3-3 proteins accelerates cell death and enhances sensitivity to DNA damage-inducing drugs [31]. In addition, diminished levels of MIF, a proinflammatory cytokine capable of modulating the expression of the tumor suppressor TP53 (a.k.a. p53), ultimately causing tumor growth and invasiveness, might be

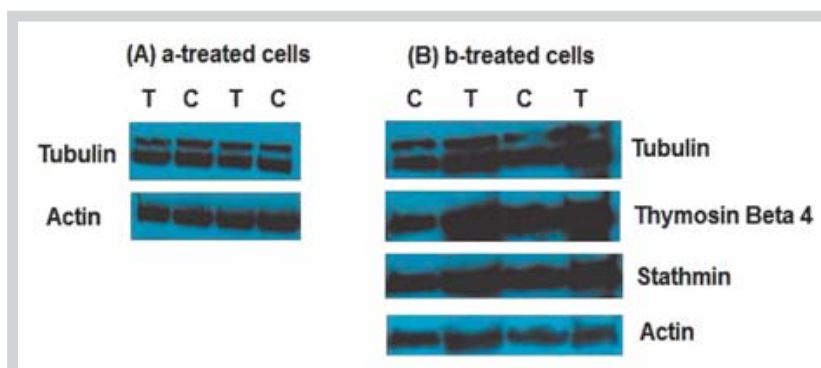

Fig. 4 Western blotting analysis of protein expression by HL-60 cells. A Cells treated with $1.65 \mu \mathrm{M}$ (a) from RIPA lysate; and B Cells treated with $0.4 \mu \mathrm{M}$ (b) from urea lysate. T: treated cells; C: control cells. (Color figure available online only.)

adding some effect in the cell cycle regulation and consequent inhibition of cell growth. MIF is overexpressed in several types of cancer and its blocking has been proposed as a strategy in the control of chronic lymphocytic leukemia [32]. Myeloperoxidase (MPO) has also been detected at high levels in a number of leukemia types. Promyelocytes and promyelomonocytes produce MPO during inflammation and under oxidative stress conditions [33]. High levels of MPO can generate reactive oxygen species (ROS) that are considered the lynchpin in leukemia relapse and drug resistance $[34,35]$. The observed decrease in MPO and MIF indicates an apparent anti-inflammatory/antioxidant action of (a). It is interesting to note that anti-MIF immunoglobulin and nonsteroidal, anti-inflammatory drugs are employed in conjunction with other chemotherapeutic agents in the treatment of some types of cancer [36].

Thymosin $\beta 4$ (TB4) operates in cytoskeleton reorganization, sequestering gamma actin and impairing its polymerization, which consequently plays a role in the maintenance of mitochondrial integrity and scavenging of ROS, indirectly protecting cells from oxidative damage. Decreased levels of TB4 induce significant increases of ROS and disruption of the mitochondrial morphology in human colorectal carcinoma cells [37]. Quite the opposite, increased levels of TB4 promote stabilization of the transcription factor HIF-1, whose expression is activated under hypoxia, a phenomenon that occurs during cancer progression, which eventually increases the production of vascular endothelial growth factor with consequent angiogenesis and tumor metastasis. In turn, it was proposed that Rho GTPases might be upstream regulators of TB4 [38,39], a fact that corroborates the direct correlation observed between TB4/RhoGDI2 expressed levels either in (a)- or (b)-treated cells ( $O$ Table 3). TB4 was also shown to downregulate inflammatory mediators like matrix metalloproteinases (MMPs) and to increase production of the anti-inflammatory cytokine IL-10 [40].

\section{Materials and Methods \\ $\nabla$}

\section{Compounds' origin}

(22E,24R)-8,14-Epoxyergosta-4,22-diene-3,6-dione (a) was isolated from $P$. immersa and aphidicolin (b) from $N$. sphaerica as previously described $[3,4]$. Both are endophytic fungi from the plant Smallanthus sonchifolius (Yacon), Asteraceae. The purity of compounds (a) and (b) was assessed by GC and HPLC analyses as 98 and 99\%, respectively. 


\section{Cell culture and preparation of lysates}

HL 60 (ATCC CCL-240) cells were cultured in $5 \times 250 \mathrm{~mL}$ Falcon tissue culture flasks containing $40 \mathrm{~mL}$ of RPMI 1640 medium (GIBCO/Invitrogen) supplemented with 10\% FBS (triple $0.1 \mu \mathrm{m}$ sterile-filtered, Gemini Bio-Products) and $1 \%$ of 100 u penicillin/ streptomycin (Sigma-Aldrich), at $37^{\circ} \mathrm{C}$ under a $5 \% \mathrm{CO}_{2}$ atmosphere in a humidified incubator. After 10 days of culture, cells grew to a density of $1.4 \times 10^{6}$ cells per flask and were treated with the test substances for an additional $48 \mathrm{~h}$ using $0.7 \mu \mathrm{g} / \mathrm{mL}$ $(1.65 \mu \mathrm{M})$ and $2.1 \mu \mathrm{g} / \mathrm{mL}(4.95 \mu \mathrm{M})$ of $(\mathbf{a})$, and $0.15 \mu \mathrm{g} / \mathrm{mL}$ $(0.4 \mu \mathrm{M})$ and $0.9 \mu \mathrm{g} / \mathrm{mL}(2.66 \mu \mathrm{M})$ of $(\mathbf{b})$. A flask containing cells treated with $0.1 \%$ DMSO (Sigma-Aldrich) was used as a vehicle control. In order to obtain the lysates, the medium of each culture flask was transferred to a $50-\mathrm{mL}$ conical Falcon tube and centrifuged at $4^{\circ} \mathrm{C} / 10 \mathrm{~min} / 1200 \mathrm{rpm}$. The supernatants were decanted and cell pellets were washed $3 \times 10 \mathrm{~mL}$ with ice-cold PBS, pH 7.4 (without Ca or Mg; Lonza), followed by centrifugation. Cell pellets were resuspended in $1.5 \mathrm{~mL}$ of modified RIPA lysis buffer by pipetting up and down. The viscous content was ice incubated for $10 \mathrm{~min}$, sonicated for $5 \mathrm{~min}$, boiled for $5 \mathrm{~min}$ inside a beaker containing water, and extensively disrupted with 25 gauge needles. The resultant material was centrifuged at $4^{\circ} \mathrm{C} / 30 \mathrm{~min} / 12000 \mathrm{~g}$. The obtained supernatants were collected, labeled "RIPA lysates", and the total protein content was quantified with the BCA protein assay according to the manufacturer's instructions (Thermo Scientific) using bovine serum albumin (BSA) as the standard. The residual pellets were submitted to a second lysis process using $1.5 \mathrm{~mL}$ of urea/thiourea lysis buffer [ $5 \mathrm{M}$ urea (EMD Chemicals, Inc.), $2 \mathrm{M}$ thiourea (Sigma-Aldrich), $50 \mathrm{mM}$ DTT (Fisher Scientific), $0.1 \%$ SDS (Bio-Rad Labs), PBS, pH 7.4] and incubated for $30 \mathrm{~min}$ at r.t. followed by centrifugation at $15^{\circ} \mathrm{C} / 30 \mathrm{~min} /$ $20000 \mathrm{~g}$. The obtained supernatants were collected, named "urea lysates", and the total protein content was quantified by the Pierce $660 \mathrm{~nm}$ protein assay (Thermo Scientific) using BSA as the standard [41].

\section{Growth inhibition}

Growth inhibition (GI) was assessed by the trypan blue dye exclusion method. For each tested compound, the GI was based on the concept of test through control $(\mathrm{T} / \mathrm{C})$, and the following equation was used: $\mathrm{GI}=100-(\mathrm{T} / \mathrm{C} \times 100)$ based on Richter et al. [42]. Control groups were treated with vehicle and doxorubicin (Doxolem, Zodiac Produtos Farmacêuticos S/A, purity $>95 \%$ ), the latter of which was used as a positive control ( $\mathrm{IC}_{50} 0.02 \mu \mathrm{g} /$ $\mathrm{mL}=0.4 \mathrm{nM})$.

\section{Isobaric tags for relative and absolute quantitation (ITRAQ) labeling and strong cation exchange (SCX) chromatography}

Before being submitted to the isobaric labeling, the urea lysates had to be cleaned in order to remove excess urea to avoid modifications of proteins at temperatures above $37^{\circ} \mathrm{C}$, rendering a protein unsuitable for enzymatic digestion [43]. Zeba desalting spin columns (Thermo Scientific) were previously conditioned with $4 \times 1 \mathrm{~mL}$ PBS, $\mathrm{pH} 7.4$, and centrifuged for $2 \mathrm{~min} /$ r.t./ $1200 \mathrm{rpm}$. An aliquot of lysate corresponding to $100 \mu \mathrm{g}$ of protein was speed-vacuum dried and resuspended in $1000 \mu \mathrm{L}$ of PBS, $\mathrm{pH}$ 7.4. The obtained solution was split into five separate $200 \mu \mathrm{L}$ aliquots in $1.5-\mathrm{mL}$ Eppendorf tubes, followed by dilution of each to $700 \mu \mathrm{L}$ with PBS, pH 7.4. Each of these was loaded into separate Zeba columns. After complete sample absorption, the tubes were centrifuged for $2 \mathrm{~min} / 4^{\circ} \mathrm{C} / 1200 \mathrm{rpm}$ and the collected liquid was dried. The five samples were recombined by pipetting up and down $20 \mu \mathrm{L}$ of dissolution buffer in the first tube, followed by vortexing, spinning, and transfer to the second tube; the procedure was repeated until the fifth tube.

Urea or RIPA lysates were reduced, alkylated, digested, and labeled essentially as recommended by the iTRAQ 8-plex reagents manufacturer's protocol (Applied Biosystems), followed by a cleanup procedure using off-line SCX chromatography, which was carried out using polysulfoethyl $\mathrm{A}^{\mathrm{TM}}$ macro spin columns $25-150 \mu \mathrm{L}$, (PolyLC, Inc.), previously conditioned using $1 \times 500 \mu \mathrm{L} \mathrm{MeOH}$ (to activate the stationary phase; centrifuge the tube for $1 \mathrm{~min} / 800 \mathrm{rpm}$ ), followed by $2 \times 500 \mu \mathrm{L}$ of $18 \mathrm{mOhm}$ water (to prevent salt precipitation; centrifuge the tube for $1 \mathrm{~min} / 800 \mathrm{rpm}$ ), and then $1 \times 500 \mu \mathrm{L}$ of $0.2 \mathrm{M}$ monosodium phosphate $/ 0.3 \mathrm{M}$ sodium acetate, $\mathrm{pH} 3.0$ (span for $10 \mathrm{~s} / 800 \mathrm{rpm}$, stood in the tube for $1 \mathrm{~h}$ ). The stationary phase was equilibrated with $3 \times 500 \mu \mathrm{L} 10 \mathrm{mM}$ potassium phosphate, $\mathrm{pH} 3.0$, in $20 \% \mathrm{ACN}$, then centrifuged for $1 \mathrm{~min} / 800 \mathrm{rpm}$. Before loading, the sample was completely dried then resuspended in $200 \mu \mathrm{L}$ of equilibration buffer. After loading, the column was centrifuged for $2 \mathrm{~min}$ at $1000 \mathrm{rpm}$, followed by washing with $2 \times 100 \mu \mathrm{L}$ of equilibration buffer, then centrifuged for $1 \mathrm{~min} / 1000 \mathrm{rpm}$. Peptides were eluted from the stationary phase using $100 \mu \mathrm{L}$ of the equilibration buffer solutions containing 40 to $500 \mathrm{mM} \mathrm{KCl}$ (Sigma), respectively, and centrifuged for $1 \mathrm{~min} / 1000 \mathrm{rpm}$. After elution, all samples were speed-vacuum dried and reconstituted in $16 \mu \mathrm{L}$ of $2 \%$ ACN (HPLC grade; Mallinckrodt)/0.1\% TFA (99+\% spectrophotometric grade; Sigma-Aldrich) in water (HPLC grade; Burdick \& Jackson). Samples were stored at $-20^{\circ} \mathrm{C}$ until LC-MS analysis.

\section{LC-MS analysis}

Peptide separation was performed on a Famos/Switchos/Ultimate $^{\mathrm{TM}}$ chromatography system (Dionex/LC Packings). Individual labeled-SCX aliquots $(5 \mu \mathrm{L})$ were desalted for 10 min onto a $C_{18}$ guard column $(0.3 \times 5 \mathrm{~mm}, 5 \mu \mathrm{m}, 100 \AA$, LC Packings) using $2 \%$ $\mathrm{ACN} / 0.1 \% \mathrm{TFA}$ in water at $30 \mu \mathrm{L} / \mathrm{min}$. Peptides were separated in a Dionex ProteoPep ${ }^{\mathrm{TM}} \mathrm{C}_{18}$ column $(0.075 \times 150 \mathrm{~mm} ; 3 \mu \mathrm{m}$ particle size, $100 \AA$ ) using solvent A ( $5 \%$ ACN/0.1\% TFA in water) and solvent B (85\% ACN $/ 0.1 \% \mathrm{TFA} / 5 \%$ isopropyl alcohol in water) in a 160 -min multistep gradient consisting of $10 \%$ solvent $B$ for 40 min, followed by a 20 -min linear gradient until $20 \%$ B, maintained for $50 \mathrm{~min}$, increased to $30 \% \mathrm{~B}$ in $20 \mathrm{~min}$ and maintained for 50 min, and finally a 10 -min linear gradient until $100 \%$ B at a flow rate of $0.25 \mu \mathrm{L} / \mathrm{min}$. The peptide elution was monitored at 214 and $280 \mathrm{~nm}$. The outlet of the UV was coupled with a Probot MALDI-plate spotting device operating with Carrier software v. 1.47 (LC Packings). During separation, a saturated solution of $31.7 \mathrm{mM}$ CHCA ( $\alpha$-cyano-4-hydroxycinnamic acid; Sigma) in $80 \% \mathrm{ACN} / 0.1 \%$ TFA in water containing $10 \mathrm{mM}$ ammonium citrate dibasic (Fluka Analytical) and $25 \mathrm{fmol} / \mu \mathrm{L}$ of angiotensin II (AGT II, for internal calibration; Sigma) was continuously added to the eluant by the Probot system at a flow rate of $0.5 \mu \mathrm{L} / \mathrm{min}$. Samples were spotted every $12.5 \mathrm{~s}$ of the LC run onto stainless steel MALDI plates (blank opti-TOFTM LC/MALDI insert $123 \times 81 \mathrm{~mm}$, Applied Biosystems) totaling 768 spots ( $=$ LC fractions) per sample. Plates were stored in the dark until the MS and MS/MS spectra were acquired. For MALDI-TOF-MS and -MS/MS analyses, eight mass calibration spots [ $0.75 \mu \mathrm{L}$ of a solution containing $1 \mu \mathrm{L}$ of a six-protein mix (Applied Biosystems) stock solution $(1: 20)$ and $24 \mu \mathrm{L}$ of saturated CHCA solution] were manually pipetted on the 8-perimeter wells of the plate and dried at r.t. MALDI-TOF-MS data were acquired automatically over a mass range of 900 to 
$4000 \mathrm{Da}$, focus mass of 2100 , in the positive ion-reflector mode on a 4800 Plus proteomics analyzer matrix-assisted laser desorption ionization (MALDI) time-of-flight (TOF) mass spectrometer (Applied Biosystems) using a fixed laser intensity for 1000 shots/ spectrum, and a uniformly random spot search pattern. MS and MS/MS data acquisition were controlled by 4000 series Explorer v 3.0 software. After plate alignment, external calibration, and internal calibration for each MALDI plate, an MS spectrum was acquired for each of the 768 spots. The mass spectra were subjected to an interpretation method, which selected the 10 most intense precursors from each spot excluding ions with an $\mathrm{S} / \mathrm{N}$ less than 20 , filtering out identical peaks detected in adjacent spots with a mass tolerance of $200 \mathrm{ppm}$, an exclusion list tolerance of $0.1 \mathrm{~m} / \mathrm{z}$, and minimum chromatogram peak width of 2 fractions. MS/MS acquisition started from the strongest precursors first. The collision induced dissociation (CID) used a collision cell floated at $2 \mathrm{kV}$ and air as the collision gas; the relative precursor mass window was set at 300 FWHM (full width half mass) with suppression of the precursor ion and metastable ions unfocused; the spectra were acquired for the selected precursors using 3000 shots/spectrum with 75 shots/sub-spectrum. The stop-condition criterion was determined to the 40 sub-spectra acquisition, passing or failing. The internal one-point calibration utilized $\mathrm{m} / \mathrm{z}$ of the monoisotopic molecular ion of AGT II to match the minimum $\mathrm{S} / \mathrm{N}$ of 200 , a mass tolerance of $\pm 0.5 \mathrm{~m} / \mathrm{z}$, a mass error of $5 \mathrm{ppm}$, and a minimum peak width at 2.9 bins. When the acceptance criteria were not met, a default calibration based on a multi-parameter calibration equation was employed.

\section{Proteomics analysis}

Protein identification and quantitation for the ITRAQ experiments were performed with ProteinPilot v. 3.0 software (Applied Biosystems) using the Paragon protein database search algorithm. The data analysis parameters were as follows: Sample type: iTRAQ 8-plex (peptide labeled); Cys alkylation: MMTS (methyl methanethiosulfonate); digestion: trypsin; instrument: 4800; special factors: none for RIPA lysates, and urea denaturation for urea lysates; ID Focus: biological modifications - searches for over 170 potential modifications. iTRAQ labeled lysine, iTRAQ $\mathrm{N}$-terminal labeling, and MMTS alkylation of cysteine were used as fixed modifications; oxidation of methionine and iTRAQ labeling of tyrosine were used as variable modifications. Database searching: ipi.HUMAN v.3.61; search effort: thorough ID; minimum detected protein threshold [unused ProtScore (conf)]: $99 \%$. The relative quantification was based on the ratio of the reporter ions corresponding to the urea or RIPA tryptic peptides from treated HL 60 cells over the reporter ion corresponding to the urea or RIPA tryptic peptides from the control. Proteins giving tryptic peptides with an average reporter ion ratio $\geq 2$ were classified as upregulated and those with an average reporter ion ratio $\leq 0.9$ were classified as downregulated ( $\mathrm{p} \leq 0.05$ ). Protein ontology was determined using the UniProtKB/Swiss Prot databank.

\section{Cell cycle arrest studies}

The assay involves the fixation and permeabilization of cells using $70 \%$ ethanol, making the staining of DNA within intact cells by propidium iodide (PI; Sigma-Aldrich) possible. HL-60 cells were grown in $12 \times 100 \mathrm{ml}$ petri dishes; each plate contained $10 \mathrm{~mL}$ of RPMI 1640 medium supplemented with $10 \%$ FBS and $1 \%$ of $100 \mathrm{u}$ penicillin/streptomycin, at $37^{\circ} \mathrm{C}$ under a $5 \% \mathrm{CO}_{2}$ atmosphere in a humidified incubator. When cells were confluent, they were treated with the vehicle $(0.1 \%$ DMSO, negative con- trol), 95\% S-(+)-camptothecin $(10 \mu \mathrm{M}$, positive control; Sigma), or test compounds [0.15 and $0.9 \mu \mathrm{g} / \mathrm{mL}$ (b); 0.7 and $2.1 \mu \mathrm{g} / \mathrm{mL}$ (a)] for $48 \mathrm{~h}$. Two independent experiments were carried out. Cellular DNA content was quantified by flow cytometric determination of PI intercalated into DNA of intact, fixed cells. Drug- or vehicle-treated cells $\left(1 \times 10^{6}\right)$ were collected, twice washed with iced PBS, resuspended in PBS, and fixed with $70 \%$ ethanol at $-20^{\circ} \mathrm{C}$ for $48 \mathrm{~h}$. Cells were pelleted by centrifugation and then treated with $1 \mathrm{~mL}$ of PI staining solution [20 $\mu \mathrm{g} / \mathrm{mL}$ RNase A (Sigma) and $50 \mu \mathrm{g} / \mathrm{mL}$ PI as final concentrations] at $37^{\circ} \mathrm{C}$ for $30 \mathrm{~min}$ in the dark, and cells were stored in the dark at $4{ }^{\circ} \mathrm{C}$ until analyzed $(72 \mathrm{~h})$. DNA content was determined on a BD LSRII special order system flow cytometer (BD Biosciences), equipped with a $488 \mathrm{~nm}$ Ar laser, by measuring forward and orthogonal light scatter, and peak and area red fluorescence. Acquisition of data was performed by FACSDiva software and analyzed by FlowJo software. Statistical analysis was performed by Student's t-test using a significance level of $\mathrm{p}<0.05$.

\section{Apoptosis analysis}

Apoptosis assays were performed according to the manufacturer's protocol (Invitrogen). Briefly, cells were cultured similarly to cell cycle analysis. Drug- or vehicle-treated cells $\left(1 \times 10^{6}\right)$ were collected, washed twice with iced PBS, and resuspended in $100 \mu \mathrm{L}$ annexin-binding buffer ( $1: 10 \mathrm{v} / \mathrm{v}$ in $18 \mathrm{mOhm}$ water). Aliquots of $5 \mu \mathrm{L}$ of 7 -aminoactinomycin D $(1: 20 \mathrm{v} / \mathrm{v}$ in PBS) and annexin $\mathrm{V}$-pacific blue conjugate were added, and the sample was incubated at r.t. for $15 \mathrm{~min}$ in the dark. An amount of $400 \mu \mathrm{L}$ annexin-binding buffer was added and gently agitated. Samples were maintained on ice until analyzed. The proportion of apoptotic cells was determined in a BD FACSAria analyzer (BD Biosciences) using a fluorescence excitation at $410 \mathrm{~nm}$ and an emission at $455 \mathrm{~nm}$.

We considered aphidicolin as the positive control in this experiment since it is known to cause apoptosis in HL-60 cells at the tested dosages [8].

\section{Electron microscopy}

HL-60 cells were cultured and treated in triplicate similarly to the lysates preparation method. Cells were harvested, twice washed with PBS pH 7.4, and then pelleted by low-speed centrifugation. The pellet was fixed with a solution containing $2.5 \%$ glutaraldehyde (Sigma), 2.0\% paraformaldehyde (Sigma), $0.1 \mathrm{M}$ sodium cacodylate (Sigma-Aldrich), and $2.5 \mathrm{mM}$ dihydro calcium chloride (Synth) in water for $72 \mathrm{~h}$ at $4^{\circ} \mathrm{C}$. For scanning electron microscopy, fixed cells were incubated at $37^{\circ} \mathrm{C}$ for $90 \mathrm{~min}$ on pretreated poly L-lysine (Sigma-Aldrich) slides. After being rinsed with iced $0.1 \mathrm{M}$ sodium cacodylate, cells were post-fixed $1 / 1 /(\mathrm{v} / \mathrm{v})$ with $2 \%$ osmium tetroxide (Sigma-Aldrich) in water plus $1.6 \%$ potassium ferricyanide (Sigma)-10 mM calcium chloride and 0.2 M sodium cacodylate for $15 \mathrm{~min}$ in the dark. After being in contact with $0.1 \mathrm{M}$ sodium cacodylate for $2 \mathrm{~min}$, the slides were washed three times with the same solution and dehydrated with an aqueous ethanol solution gradient, followed by $\mathrm{CO}_{2}$ critical-point drying using a Leica EM CPD030 apparatus. The specimens mounted on stubs were coated with gold, examined with a scanning electron microscope (JSM-6390LV, JEOL), and photographed. For transmission electron microscopy, the cells were fixed and post-fixed similarly to SEM, dehydrated in a graded acetone series, and embedded in Poly Bed 812 resin (Polysciences, Inc.). Ultrathin sections were obtained, counterstained with $7 \%$ uranium acetate 
and lead citrate (both from Sigma-Aldrich), and examined with a transmission electron microscope (JEM-1230, JEOL).

\section{Western blotting}

Proteins were loaded at $20 \mu \mathrm{g} / \mathrm{lane}$, electrophoresed on $8 \%$ SDSpolyacrylamide gels, transferred onto nitrocellulose membranes, blocked with $5 \%$ milk in PBS Tween, and immunoblotted with mouse monoclonal anti-TMSB4X (clone 4H7; Abnova), mouse monoclonal anti-STAT1 (clone 1A8; Abnova), mouse monoclonal anti-tubulin (T0198, Sigma), and rabbit polyclonal anti-gamma actin (F-3022, Sigma) at a dilution of 1:1000 and incubated overnight at r.t., followed by incubation with horseradish peroxidase (HRP)-conjugated goat anti-mouse IgG (Abcam) or HRP-conjugated goat anti-rabbit polyclonal IgG (Abcam) secondary antibodies at a dilution of $1: 25000$ for $1 \mathrm{~h}$. The development was carried out using an enhanced chemiluminescence system (Amersham Pharmacia).

\section{Acknowledgements}

$\nabla$

The authors are thankful to the CPqGM Microscopy Core Facility for allowing the SEM and TEM micrographs. This work was supported by Fundação de Amparo à Pesquisa do Estado de São Paulo (FAPESP), Fundação de Amparo à Pesquisa do Estado da Bahia (FAPESB), Conselho Nacional de Desenvolvimento Científico e Tecnológico (CNPq), and the Department of Defense Congressionally Directed Medical Research Program Breast Cancer Research, that also provided scholarships for some of the authors.

\section{Conflict of Interest}

$\nabla$

The authors declare no conflict of interest.

\section{Affiliations}

${ }^{1}$ Department of Pharmaceutical Sciences, University of Pittsburgh, Pittsburgh, PA, USA

2 Department of Pharmaceutical Sciences, Faculdade de Ciências Farmacêuticas de Ribeirão Preto - USP, Ribeirão Preto, SP, Brazil

${ }^{3}$ Mass Spectrometry Core Facility, Centro de Pesquisas Gonçalo Moniz (CPqGM) - FIOCRUZ, Salvador, BA, Brazil

${ }^{4}$ Department of Pharmacology \& Chemical Biology, University of Pittsburgh, Pittsburgh, PA, USA

${ }^{5}$ Department of Structural Biology, University of Pittsburgh, Pittsburgh, PA, USA

${ }^{6}$ Núcleo de Biotecnologia e Bioprospecção, Escola Bahiana de Medicina e Saúde Pública, Salvador, BA, Brazil

${ }^{7}$ Center for Vaccine Research, University of Pittsburgh, Pittsburgh, PA, USA

\section{References}

1 National Cancer Institute. Leukemia. Available at http://www.cancer. gov/cancertopics/types/leukemia, from National Cancer Institute. Accessed October 30, 2013

$2 \mathrm{Mi} \mathrm{J}$. Current treatment strategy of acute promyelocytic leukemia. Front Med 2011; 5: 341-347

3 Gallo MBC, Chagas FO, Almeida MO, Macedo CC, Cavalcanti BC, Barros FWA, de Moraes MO, Costa-Lotufo LV, Pessoa C, Bastos JK, Pupo MT. Endophytic fungi found in association with Smallanthus sonchifolius (Asteraceae) as resourceful producers of cytotoxic bioactive natural products. J Basic Microbiol 2009; 49: 142-151

4 Gallo MBC, Cavalcanti BC, Barros FWA, de Moraes MO, Costa-Lotufo LV, Pessoa C, Bastos JK, Pupo MT. Chemical constituents of Papulaspora immersa, an endophyte from Smallanthus sonchifolius (Asteraceae), and their cytotoxic activity. Chem Biodivers 2010; 7: 2941-2950
5 Krokan $H$, Wist E, Krokan RH. Aphidicolin inhibits DNA synthesis by DNA polymerase and isolated nuclei by a similar mechanism. Nucleic Acids Res 1981; 9: 4709-4719

6 O'Dwyer PJ, Moyer JD, Suffness M, Harrison SD, Cysyk R, Hamilton TC, Plowman J. Antitumor activity and biochemical effects of aphidicolin glycinate (NSC 303812) alone and in combination with cisplatin in vivo. Cancer Res 1994; 54: 724-729

7 Schimke RT, Kung A, Sherwood SS, Sheridan J, Sharma R. Life, death and genomic change in perturbed cell cycles. Trans R Soc B Biol Sciences 1994; 345: 311-317

8 Kurose A, Tanaka T, Huang X, Traganos F, Darzynkiewicz Z. Synchronization in the cell cycle by inhibitors of DNA replication induces histone H2AX phosphorylation: an indication of DNA damage. Cell Prolif 2006; 39: 231-240

9 Csapó Z, Sasvári-Székely M, Spasokoukotskaja T, Talianidis I, Eriksson S, Staub M. Activation of deoxycytidine kinase by inhibition of DNA synthesis in human lymphocytes. Biochem Pharmacol 2001; 61: 191-197

10 Chou RH, Chervenick PA. Combined effects of aphidicolin and retinoic acid on proliferation and differentiation on human leukemic (HL-60) cells. Cell Tissue Kinet 1985; 18: 387-397

11 Kobayashi M, Lee NK, Son BW, Yanagi K, Kyogoku Y, Kitagawa I. Stoloniferone-A, $-B,-C$, and $-D$, four new cytotoxic steroids from the Okinawa soft coral Clavularia viridis. Tetrahedron Lett 1984; 25: 5925-5928

12 Samadi AK, Tong X, Mukerji R, Zhang H, Timmermann BN, Cohen MS. Withaferin A, a cytotoxic steroid from Vassobia breviflora, induces apoptosis in human head and neck squamous cell carcinoma. J Nat Prod 2010; 73: 1476-1481

13 de Ridder MC, Van Der Plas AJ, Erpelinck-Verschueren CAJ, Wenberg BL, Jansen $J H$. Dexamethasone does not counteract the response of acute promyelocytic leukaemia cells to all-trans retinoic acid. British J Haematol 1999; 106: 107-110

14 Distelhorst $C W$. Recent insights into the mechanism of glucocorticosteroid-induced apoptosis. Cell Death Differ 2002; 9: 6-19

15 Van Waes $C$. Nuclear factor-kB in development, prevention, and therapy of cancer. Clin Cancer Res 2007; 13: 1076-1082

16 Laane E, Tamm KP, Buentke E, Ito K, Khahariza P, Oscarsson J, Corcoran $M$, Björklund AC, Hultenby K, Lundin J, Heyman M, Söderhäll S, Mazur J, Porwit A, Pandolfi PP, Zhivotovsky B, Panaretakis T, Grandér D. Cell death induced by dexamethasone in lymphoid leukemia is mediated through initiation of autophagy. Cell Death Diff 2009; 16: 1018-1029

17 Dunn jr. WA. Studies on the mechanisms of autophagy: formation of the autophagic vacuole. J Cell Biol 1990; 110: 1923-1933

18 Li L, Han W, Gu Y, Qiu S, Lu Q Jin J, Luo J, Hu X. Honokiol induces a necrotic cell death through the mitochondrial permeability transition pore. Cancer Res 2007; 67: 4894-4903

19 Bera TK, Walker DA, Sherins RJ, Pastan I. POTE protein, a cancer-testis antigen, is highly expressed in spermatids in human testis and is associated with apoptotic cells. Biochem Biophys Res Communic 2012; 417: $1271-1274$

20 Choi MR, Groot M, Drexler HCA. Functional implications of caspase-mediated RhoGDI2 processing during apoptosis of HL60 and K562 leukemia cells. Apoptosis 2007; 12: 2025-2035

21 Cui J, Li W, Wang J, Li A, Li H, Wang H, He K, Li W, Kang L, Yu M, Shen B, Wang $G$, Zhang $X$. Proteomics-based identification of human acute leukemia antigens that induce humoral immune response. Mol Cell Proteomics 2005; 4: 1718-1724

22 Arntzen MØ, Thiede B. Apoptoproteomics, an integrated database for analysis of proteomics data obtained from apoptotic cells. Mol Cell Proteomics 2012; 11: M111.010447

23 Jaffe $A B$, Hall A. Rho GTPases: biochemistry and biology. Annu Rev Cell Dev Biol 2005; 21: 247-269

24 Lee DH, Chung K, Song JA, Kim TH, Kang H, Huh JH, Jung SG, Ko JJ, An HJ. Proteomic identification of paclitaxel-resistance associated hnRNP A2 and GDI 2 proteins in human ovarian cancer cells. J Proteome Res 2010; 9: 5668-5676

25 Rubin CI, Atweh GF. The role of stathmin in the regulation of the cell cycle. J Cell Biochem 2004; 93: 242-250

26 Bhalla KB. Microtubule-targeted anticancer agents and apoptosis. Oncogene 2003; 22: 9075-9086

27 Chakravarti D, Hong R. SET-ting the stage for life and death. Cell 2003; 112: 589-593

28 Sancho M, Diani E, Beato M, Jordan A. Depletion of human histone H1 variants uncovers specific roles in gene expression and cell growth. PLoS Genetics 2008; 4: 1-17 
29 Fazal F, Bijli KM, Minhajuddin M, Rein T, Finkelstein JN, Rahman A. Essential role of cofilin- 1 in regulating thrombin-induced RelA/p 65 nuclear translocation and intercellular adhesion molecule 1 (ICAM-1) expression in endothelial cells. J Biol Chem 2009; 284: 21 047-21 056

30 Assinder SJ, Stanton JAL, Prasad PD. Transgelin: an actin-binding protein and tumour suppressor. Int J Biochem Cell Biol 2009; 41: 482-486

31 Giardino AK, Yaffe MB. 14-3-3 Proteins as signaling integration points for cell cycle control and apoptosis. Semin Cell Dev Biol 2011; 22: 688-695

32 Shachar I, Haran $M$. The secret second life of an innocent chaperone: the story of CD74 and B cell/chronic lymphocytic leukemia cell survival. Leuk Lymphoma 2011; 52: 1446-1454

33 Stanković S, Majkić-Singh N. Myeloperoxidase: new roles for an old molecule. J Med Biochem 2011; 30: 230-236

34 Sarmento-Ribeiro AB, Proença MT, Sousa I, Pereira A, Guedes F, Teixeira $A$, Oliveira $C R$. A possible role for oxidation stress in lymphoid leukaemias and therapeutic failure. Leuk Res 2012; 36: 1041-1048

35 Rollins-Raval MA, Roth CG. The value of immunohistochemistry for CD14, CD123, CD33, myeloperoxidase and CD68R in the diagnosis of acute and chronic myelomonocytic leukaemias. Histopathol 2012; 60: 933-942

36 Conroy H, Mawhinney L, Donnelly SC. Inflammation and cancer: macrophage migration inhibitory factor (MIF)-the potential missing link. Q J Med 2010; 103: 831-836
37 Tang $M C$, Su Y. Thymosin $\beta_{4}$ knockdown disrupts mitochondrial functions of SW480 human colon cancer cells. Cancer Sci 2011; 102: $1665-1672$

38 Jo JO, Kang YJ, Ock MS, Kleinman HK, Chang HK, Cha H. Thymosin $\beta_{4}$ expression in human tissues and in tumors using tissue microarrays. J Appl Immunohistochem Mol Morphol 2011; 19: 160-167

39 Moon EY, Im YS, Ryu YK, Kang JH. Actin-sequestering protein, thymosin beta-4, is a novel hypoxia responsive regulator. Clin Exp Metastasis 2010; 27: 601-609

40 Crockford D, Turjman N, Allan C, Angel J. Thymosin $\beta_{4}$ : structure, function, and biological properties supporting current and future clinical applications. Ann N Y Acad Sci 2010; 1194: 179-189

41 Antharavally BS, Mallia KA, Rangaraj P, Bell PA. Quantitation of proteins using a dye-metal-based colorimetric protein assay. Anal Biochem 2009; 385: 342-345

42 Richter L, Ruckert $U$, Kramer S. Learning a predictive model for growth inhibition from the NCI DTP human tumor cell line screening data: does gene expression make a difference? Pacific Symp Biocomp 2006; 11: 596-607

43 McCarthy J, Hopwood F, Oxley D, Laver M, Castagna A, Righetti PG, Williams $K$, Herbert BJ. Carbamylation of proteins in 2-D electrophoresis myth or reality? Proteome Res 2003; 2: 239-242 